\title{
MICROBIOLOGICAL QUALITY ASSESSMENT OF DATE PALM FRUITS AND DEVELOPMENT OF A DECONTAMINATION METHOD
}

\author{
MS KABIR*, MS AKTER, T Hossan ${ }^{1}$ AND MI KhaliL ${ }^{1}$ \\ Department of Botany, Jahangirnagar University, Savar, Dhaka-1342, Bangladesh
}

Keywords: Date palm, Fruit, Microbiological quality, 16S rRNA gene, Vinegar

\begin{abstract}
Microbiological quality of four different cultivars (viz., Deglet Noor, Dabbas, Barni and Lulu) of date palm fruits imported into Bangladesh was evaluated. The microbiological quality analysis revealed that the date palm fruit samples are contaminated with bacteria and fungi. Among the studied samples, total aerobic plate count varied from $6.85 \times 10^{6} \mathrm{cfu} / \mathrm{g}$ to $4.14 \times 10^{7} \mathrm{cfu} / \mathrm{g}$. The maximum bacterial load was observed in 'Dabbas' cultivar and lowest bacteria load was found in 'Lulu' cultivar. The total yeast and mold count ranged from $1.08 \times 10^{3} \mathrm{cfu} / \mathrm{g}$ to $6.94 \times 10^{4} \mathrm{cfu} / \mathrm{g}$. The maximum yeast and mold count was found in 'Deglet Noor' cultivar whereas this count was lowest in 'Lulu' cultivar. Twenty-two bacterial isolates were randomly selected and identified based on their morphological, cultural and biochemical characteristics. Among the bacterial isolates, Providencia rettgeri was most prevalent $(18.18 \%)$. The identity of one of the P. rettgeri isolates was confirmed by its $16 \mathrm{~S}$ rRNA gene sequence comparison and subsequent molecular phylogenetic analysis. The presence of pathogenic bacteria in the imported date palm fruits indicates that they are not suitable for direct human consumption. To improve the microbiological quality of the date palm fruits, several easily available substances were tested as decontaminating agent. The study revealed that commercially available vinegar acts as an excellent decontaminating agent against date palm fruit-associated bacteria.
\end{abstract}

\section{Introduction}

The date palm fruit (Phoenix dactylifera L.) is a single, oblong, one-seeded berry, with a terminal stigma, a fleshy pericarp, a mesocarp, a membranous endocarp (between the seed and the flesh) and a seed. The mesocarp is the largest part, which is composed of parenchymatous cells that are separated into an outer mesocarp and an inner mesocarp with intermediate layers of tanniferous cells (Shomer et al. 1998).

Date palm fruit is rich in nutrients and due to its dietetic values it has always been held in high esteem by people. Date fruits are composed of $70 \%$ carbohydrates, mostly sugars, and $15 \%-$ $30 \%$ water. Dates are also a good source of different minerals, including iron, potassium and calcium, as well as low amounts of sodium and fat (Thabet et al. 2010, Dayani et al. 2012). In most of the cultivars, the sugar content of a date fruit is almost entirely of the inverted form (viz., glucose and fructose), important for persons who cannot tolerate sucrose. The invert sugar in dates is immediately absorbed by the human body without being subjected to digestion that ordinary sugar undergoes. Date palm fruits are also a good source of antioxidants, mainly carotenoids and phenolics (Al-Farsi and Lee 2008).

Microbial contaminants present in fruits may cause deterioration of the fruit quality and serious diseases in humans. The source of these microbial contaminants may be the irrigation water, soil, manure, wild animals, insects, harvesting equipment, rinse water, packaging personnel and the environment of the processing facility (Falkiner 1998, Beuchat 2002, Berger et al. 2010, Maffei et al. 2016). Food borne illnesses are still a major concern for producers, consumers and

*Author for correspondence: <shahin@juniv.edu>. ${ }^{1}$ Department of Biochemistry and Molecular Biology, Jahangirnagar University, Savar, Dhaka-1342, Bangladesh. 
public health authority. Synthetic disinfectants are generally used on fruits to inhibit or inactivate spoilage and pathogenic microorganisms. However, consumers have a lot of questions on the safety of disinfectants used in fruits. In recent decades an increasing tendency towards the use of natural substances instead of the synthetic ones has been observed (Saleh and Otaibi 2013).

In Bangladesh, date palm fruits imported from various countries are very popular among the people of all walks of life. Demand of this fruit reaches at the peak during the holy month of Ramadan. Several research groups have evaluated the microbiological and biochemical attributes of the date palm fruits growing in their home country (Ali 2009, Hasnaoui et al. 2010, Aleid et al. 2014). However, research on the microbiological quality of date palm fruits imported into Bangladesh is limited (Zamir et al. 2018). Furthermore, molecular identity of the bacteria associated with the imported date palm fruits and their control measures were not considered in that study. Therefore, the present study was conducted on four different cultivars of date palm fruits (viz., Deglet Noor, Dabbas, Barni and Lulu) imported into Bangladesh with the objectives to assess the microbiological quality of the date palm fruits and to develop a method to decontaminate them.

\section{Materials and Methods}

Date palm fruits available in intact packets were collected from retail shops of Dhaka city, Bangladesh. The cultivar name, weight and name of the country were recorded. The samples were brought to the Department of Botany, Jahangirnagar University (JU), Savar, Dhaka, for further analysis. A part of the study was performed in the Department of Biochemistry and Molecular Biology, JU. Some basic information of the studied fruit samples are presented in Table 1.

Table 1. Basic information on the date palm fruit used in this study.

\begin{tabular}{llll}
\hline Cultivar name & Packing size $(\mathrm{g})$ & Fruit type & Country of origin \\
\hline Deglet Noor & 250 & Soft & Algeria \\
Dabbas & 400 & Semi-soft & United Arab Emirates \\
Barni & 500 & Soft & Saudi Arabia \\
Lulu & 1000 & Semi-soft & United Arab Emirates \\
\hline
\end{tabular}

One $\mathrm{g}$ of each fruit sample was suspended in $9 \mathrm{ml}$ sterile saline $(0.9 \% \mathrm{NaCl})$ and mixed well to get 10 fold dilution of the fruit sample. After thoroughly mixing, decimal serial dilution was performed to enumerate the microbial load in the fruit samples. One hundred microliter of the suspension from the serially diluted samples were spread onto the nutrient agar (NA) medium and potato dextrose agar (PDA) medium to enumerate the total aerobic plate count (APC) and total yeast and mold count (YMC), respectively. The NA plates were incubated at $37^{\circ} \mathrm{C}$ for $24 \mathrm{hrs}$ and PDA plates were incubated at room temperature for 5 days. The APC and YMC were expressed as colony forming unit per $\mathrm{g}(\mathrm{cfu} / \mathrm{g})$ of fruit.

Twenty-two morphologically dissimilar colonies were randomly selected from NA plates and streaked on the NA plate to obtain a pure culture. The streaked plates were incubated at $37^{\circ} \mathrm{C}$ for $24 \mathrm{hrs}$. The well isolated single colony was selected and subjected to further purification through repeated plating by streaking method. The colony characteristics of the bacteria grew onto the NA plates was recorded. The selected isolates (DPB1-DPB22) were subjected to morphological, cultural and biochemical studies. At first, Gram staining, oxidase test and catalase test were performed. The API 20E (Biomerieux, France) test strips were used following manufacturer's 
instructions to identify the Gram-negative bacterial isolates. The following tests were performed by using API 20E strips: test for $\beta$-galactosidase enzyme by hydrolysis of the substrate onitrophenyl- $\beta$-D-galactopyranoside (ONPG), decarboxylation of the amino acid arginine by arginine dihydrolase (ADH), decarboxylations of the amino acid lysine by lysine decarboxylase (LDC), decarboxylations of the amino acid ornithine by ornithine decarboxylase (ODC), utilization of citrate as the only carbon source (CIT), production of hydrogen sulfide $\left(\mathrm{H}_{2} \mathrm{~S}\right)$, test for the urease (URE), detection of the tryptophan deaminase (TDA), Indole test (IND) for production of indole from tryptophan by the enzyme tryptophanase, Voges-Proskauer (VP) test for the detection of acetoin produced by fermentation of glucose by bacteria utilizing the butylene glycol pathway, test for the production of the gelatinase which liquefies gelatin (GEL), fermentation of glucose (GLU), fermentation of mannose (MAN), fermentation of inositol (INO), fermentation of sorbitol (SOR), fermentation of rhamnose (RHA), fermentation of sucrose (SAC), fermentation of melibiose (MEL), fermentation of amygdalin (AMY), and the fermentation of arabinose (ARA). Other isolates were identified based on morphological, biochemical and cultural characteristics (Holt et al. 1994, Cappuccino and Sherman 1996, Brooks et al. 2007).

To validate the identity of the bacteria obtained by morphological and biochemical tests, one isolate (DPB1) was subjected to molecular identification based on 16S rRNA gene sequencing. The genomic DNA was isolated as described previously (Kabir and Tasmim 2019). For amplification of 16S rRNA gene sequence universal primer pairs 27F (5'-GAGTTGATCC TGGCTCA-3') and 1492R (5'-GAAAGGAGGTGATCCAGC-3') were used. Amplification was carried out in an automatic thermocycler (Astec, Japan). Initial denaturation was done at $95^{\circ} \mathrm{C}$ for four minutes followed by 30 thermal cycling consisting of denaturation at $95^{\circ} \mathrm{C}$ for $30 \mathrm{~s}$, annealing at $49^{\circ} \mathrm{C}$ for $30 \mathrm{~s}$, and extension at $72^{\circ} \mathrm{C}$ for one min and $30 \mathrm{~s}$. A final extension at $72{ }^{\circ} \mathrm{C}$ for five min was done. The PCR product was loaded onto $0.8 \%$ agarose gel containing ethidium bromide solution and DNA ladder (Promega, USA) was used as a DNA size marker. Electrophoresis was done at constant voltage of $100 \mathrm{~V}$ for $1.5 \mathrm{hr}$ in a horizontal electrophoresis system and then visualized under a UV-transilluminator. The PCR product was excised from the gel and purified with the Wizard PCR SV gel and PCR clean-up system (Promega, USA).

The sequences of PCR product were determined in both directions with an ABI 3700 Genetic Analyzer ( $1^{\text {st }}$ Base Laboratory, Malaysia). The sequence was retrieved, edited and was compared pair-wise with NCBI non-redundant nucleotide database using BLAST homology search and the highest hits were used to identify the isolates (Altschul et al. 1990). The retrieved DNA sequences were aligned with ClustalW (Thompson et al. 1994) and phylogenetic tree was constructed by using MEGA7 software (Kumar et al. 2016).

The antibacterial activity of several generally available substances (viz., mustard oil, sorbitol, white vinegar, glycerol and olive oil) was evaluated against the isolated bacteria following agar well diffusion assay (Bauer et al. 1966). At first, $100 \mu \mathrm{l}$ culture of bacterial isolate was spread onto the Mueller Hinton Agar (MHA) medium and wells $(8 \mathrm{~mm}$ ) were made by using a sterile cork borer in each culture plate. Then $50 \mu \mathrm{l}$ of mustard oil, sorbitol, vinegar, glycerol and olive were placed into the wells sequentially. The plates were then incubated at $37^{\circ} \mathrm{C}$ for $24 \mathrm{hrs}$. Then the diameter of the inhibition zone was measured at nearest millimeter (CLSI 2006). Experiments were repeated three times.

To eliminate the bacterial contaminants from date palm fruits, samples were separately submerged in tubes containing either vinegar (Entani et al. 1998) or normal saline (control), homogenized and left for an hour. Then an aliquot from each of the tubes were streaked onto a NA plate side by side keeping a reasonable distance between them. After incubating at $37^{\circ} \mathrm{C}$ for 48 hrs, the plate was checked for bacterial growth. 


\section{Results and Discussion}

In the present study, only the cultivars which are available in intact packet and have proper label mentioning the cultivar name and country were considered (Table 1). The microbiological quality of four different cultivar of date palm fruits was evaluated. Furthermore, some of the bacterial isolates were identified based on morphological, cultural and biochemical characteristics. One of the bacterial isolate's identity was confirmed by its 16S rRNA gene (rDNA) sequence comparison. Additionally, a process of decontamination of date palm fruits by using low-cost easily available substances was tested.

Among the studied samples, APC was found to vary from $6.85 \times 10^{6} \mathrm{cfu} / \mathrm{g}$ to $4.14 \times 10^{7} \mathrm{cfu} / \mathrm{g}$. The maximum bacterial load was observed in 'Dabbas' cultivar and lowest bacterial load was found in 'Lulu' cultivar. The presence of yeast and mold was also observed in all the samples. The YMC ranged from $1.08 \times 10^{3} \mathrm{cfu} / \mathrm{g}$ to $6.94 \times 10^{4} \mathrm{cfu} / \mathrm{g}$. The maximum yeast and mold were observed in 'Deglet Noor' cultivar whereas this count was lowest in 'Lulu' cultivar (Table 2). These counts in all the studied fruit samples were higher than the acceptable limit prescribed in Saudi standards (SASO 1998). Presence of high level of contamination in fruits of several date palm cultivars was also reported in Saudi Arabia (Aleid et al. 2014).

Table 2. Microbial load of the studied samples.

\begin{tabular}{lll}
\hline Cultivar & APC $(\mathrm{cfu} / \mathrm{g})^{*}$ & YMC $(\mathrm{cfu} / \mathrm{g})^{*}$ \\
\hline Deglet Noor & $1.42 \pm 0.30 \times 10^{7}$ & $6.94 \pm 1.2 \times 10^{4}$ \\
Dabbas & $4.14 \pm 0.20 \times 10^{7}$ & $1.6 \pm 0.50 \times 10^{3}$ \\
Barni & $4.08 \pm 1.44 \times 10^{7}$ & $6.2 \pm 1.14 \times 10^{3}$ \\
Lulu & $6.85 \pm 0.47 \times 10^{6}$ & $1.08 \pm 0.46 \times 10^{3}$ \\
\hline
\end{tabular}

*The data represent average of 3 replications. APC: Aerobic plate count, YMC: Yeast and mold count.

The 22 bacterial colonies randomly selected for morphological and biochemical study varied in their margin, form, surface appearance, color, opacity, size and elevation. Out of the 22 isolates, $11(50 \%)$ were Gram-positive, $11(50 \%)$ were Gram- negative. The biochemical test results of the Gram-negative isolates are shown in Table 3. Among the 22 isolates, four (18.18\%) were identified as Providencia rettgeri, one (4.55\%) was Providencia alcalificiens, two $(9.09 \%)$ were Proteus mirabilis, two (9.09\%) were Pseudomonas aeruginosa, and two (9.09\%) were Stenotrophomonas maltophilia. Besides these, two (9.09\%) Micrococcus sp., two (9.09\%) Streptococcus faecalis, two (9.09\%) Staphylococccus sp., one (4.55\%) Bacillus mascerans and one $(4.55 \%)$ B. pumulis were also identified.

Based on the biochemical tests, the isolate DPB1 was identified as P. rettgeri. To confirm the identity of this isolate, 16S rRNA gene sequencing was performed. The 16S rRNA gene is a part of prokaryotic DNA which codes for an rRNA. This gene sequence plays an important role in accurate identification bacterial isolates (Woo et al. 2008). To confirm the identity of a bacterial isolate identified by morphological and biochemical tests, 16S rRNA gene was amplified by PCR. As expected, a single amplicon of about $1.5 \mathrm{~kb}$ was obtained. The obtained partial DNA sequence of the isolate was edited and compared to the DNA sequences available in the GenBank of NCBI. The BLAST search revealed that the 16S rRNA gene sequence of P. rettgeri DPB1 (GenBank accession No. MT778833) is more than 99\% identical to the published 16S rRNA gene sequence of $P$. rettgeri BML 2496 (GenBank accession No. AP023371). Furthermore, the 16S rRNA gene sequences of some representative strains of Providencia were retrieved from the GenBank database of NCBI for molecular phylogenetic analysis. The phylogenetic tree was constructed by 


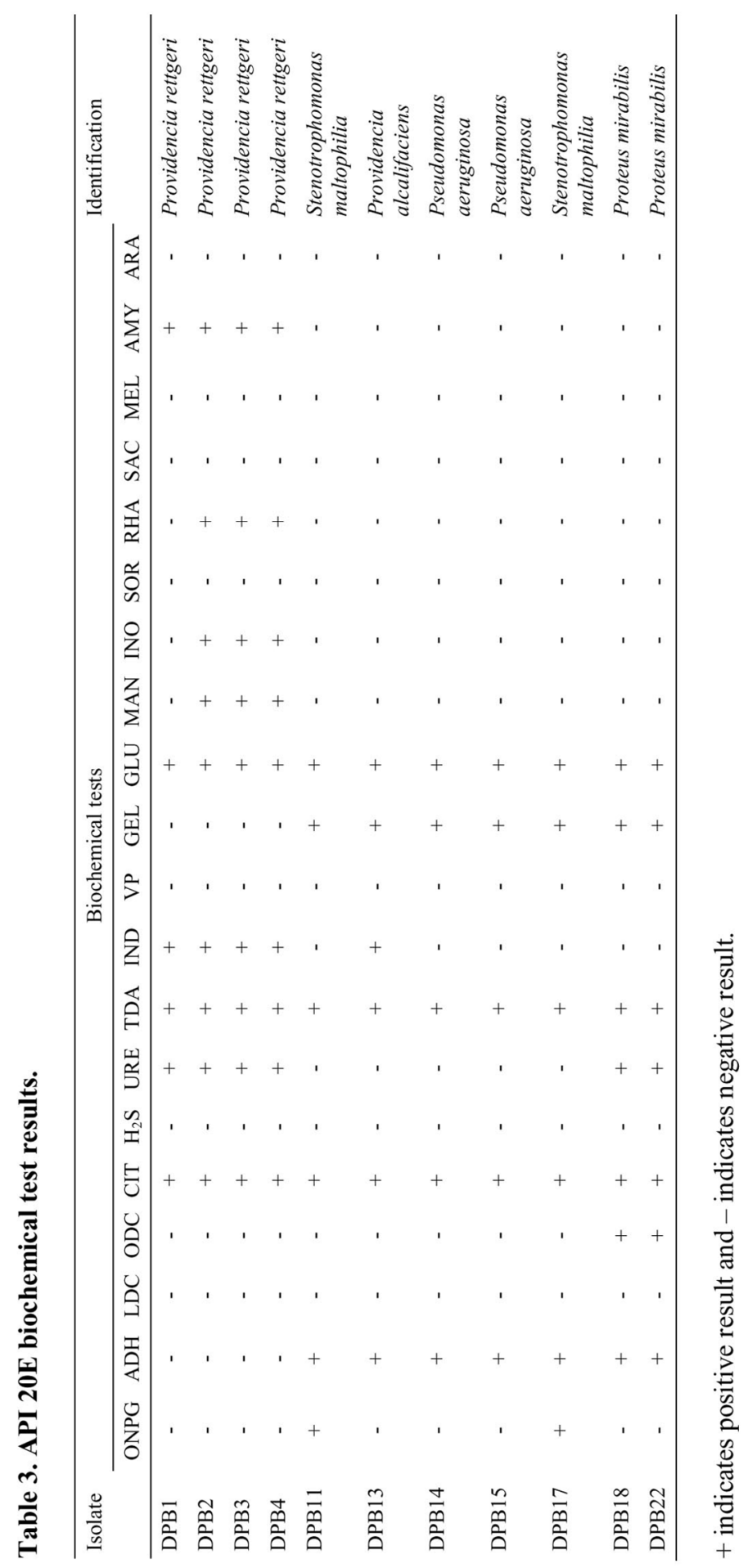


using maximum likelihood method based on the model of Tamura and Nei (1993). The tree was tested for 1000 bootstrap replicates. The percentage of trees in which the associated taxa clustered together is shown next to the branches (Fig. 1).

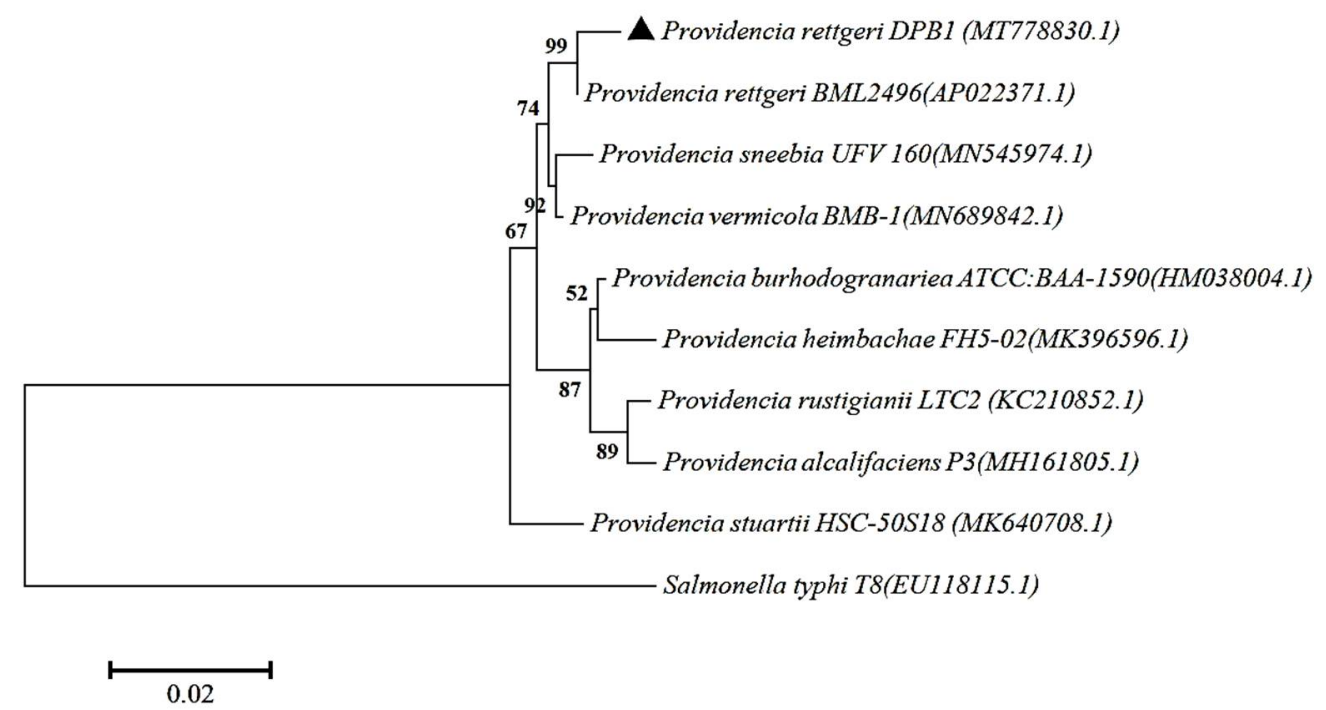

Fig. 1. Molecular Phylogenetic analysis by maximum likelihood method. Phylogenetic tree based on $16 \mathrm{~S}$ rRNA gene sequence showing the position of the strain DPB1 ( $\mathbf{\Delta})$ within Providencia. Bootstrap values on each nodes are percentage based on 1000 replicates. S. typhi was used as out group. GenBank accession numbers are shown in parenthesis.

Some of these bacterial species isolated from imported date palm fruits were not reported from local fruits (mango, orange, guava etc.) growing in Bangladesh (Islam et al. 2010, Sarker et al. 2018). Among the bacterial isolates, P. rettgeri was most prominent (18.18\%). It is noteworthy to mention here that this bacterium is responsible for traveler's diarrhea and catheterassociated urinary tract infection (Wie 2015). Another bacterium isolated from date palm fruit was identified as $P$. alcalificiens which has been implicated as a causative agent of diarrhea (Yoh et al. 2005, Yuan et al. 2020). Several studies reported that $P$. alcalificiens most frequently affects children, including travelers from developing countries. Furthermore, two large outbreaks of food borne infection caused by P. alcalificiens have been reported in Japan, Czech Republic and Kenya (Shah et al. 2015). Pseudomonas aeruginosa, an infamous opportunistic human pathogen affecting immuno-compromised patients, was also identified in the studied sample. The presence of the opportunistic pathogen Stenotrophomonas maltophilia, Proteus mirabilis, Bacillus pumulis and Staphylococcus sp. in date palm fruit samples is an indication of serious lack of hygienic practices during harvesting, post-harvest storage and packaging of the fruits.

The study revealed that the imported date palm fruits evaluated in this study contain pathogenic bacteria and are not suitable for direct human consumption. To improve the microbiological quality of the date palm fruits, several easily available substances (glycerol, mustard oil, olive oil, sorbitol and vinegar) were used to examine their antibacterial effect on the isolated bacteria. Although, glycerol, mustard oil, olive oil and sorbitol did not produce any zone of inhibition, vinegar was found highly active against all the bacterial isolates tested (DPB1DPB22) in this study. The zone of inhibition produced by vinegar ranged from $20.67 \pm 0.94$ to 32 
$\pm 1.41 \mathrm{~mm}$ (Table 4). This data clearly indicates that vinegar may be useful in controlling the bacteria associated with date palm fruits.

Table 4. Antibacterial effect of different substances against the isolated bacteria.

\begin{tabular}{lccclc}
\hline Isolates No. & \multicolumn{5}{c}{ Zone of inhibition $(\mathrm{mm})$ produced against bacterial isolates } \\
\cline { 2 - 6 } & Olive oil & Mustard oil & Sorbitol & Vinegar & Glycerol \\
\hline DPB1 & - & - & - & $30 \pm 1.63$ & - \\
DPB2 & - & - & - & $22.67 \pm 2.05$ & - \\
DPB3 & - & - & - & $24 \pm 2.94$ & - \\
DPB4 & - & - & - & $21.67 \pm 1.25$ & - \\
DPB5 & - & - & - & $32 \pm 1.41$ & - \\
DPB6 & - & - & - & $25.67 \pm 3.29$ & - \\
DPB7 & - & - & - & $23.67 \pm 1.25$ & - \\
DPB8 & - & - & - & $24 \pm 0.82$ & - \\
DPB9 & - & - & - & $21.67 \pm 1.25$ & - \\
DPB10 & - & - & - & $26.33 \pm 3.29$ & - \\
DPB11 & - & - & - & $25 \pm 2.16$ & - \\
DPB12 & - & - & - & $27.33 \pm 3.29$ & - \\
DPB13 & - & - & - & $26.33 \pm 1.25$ & - \\
DPB14 & - & - & - & $29 \pm 1.41$ & - \\
DPB15 & - & - & - & $20.67 \pm 0.94$ & - \\
DPB16 & - & - & - & $24.67 \pm 3.39$ & - \\
DPB17 & - & - & - & $23.33 \pm 2.36$ & - \\
DPB18 & - & - & - & $21.33 \pm 2.87$ & - \\
DPB19 & - & - & - & $30 \pm 1.63$ & - \\
DPB20 & - & - & - & $30 \pm 2.45$ & - \\
DPB21 & - & - & - & $26 \pm 1.41$ & - \\
DPB22 & - & - & - & $28.33 \pm 2.36$ & - \\
\hline
\end{tabular}

*" -" indicates no zone of inhibition. Data represent the average of three independent experiments.

The above-mentioned data were used to develop a method to decontaminate date palm fruits by using vinegar. For this purpose, date palm fruit samples were submerged in vinegar and in normal saline (as a control) for an hour. Streaking the vinegar-treated sample onto the nutrient agar did not produce any bacterial colony after $48 \mathrm{hrs}$ of incubation. However, sterile salinetreated sample produced bacterial colony onto nutrient agar. These findings indicate that dipping the date palm fruits in vinegar (containing 6\% acetic acid) can be used as an easy and low-cost process to decontaminate date palm fruits. Further experiments with other fruits would be helpful for large scale application of this process.

\section{References}

Aleid SM, Hassan BH, Almaiman SA, Al-Kahtani SH and Ismail SM 2014. Microbial loads and physicochemical characteristics of fruits from four Saudi date palm tree cultivars: conformity with applicable date standards. Food and Nutrition Sci. 5(4): 316-327.

Al-Farsi MA and Lee CY 2008. Nutritional and functional properties of dates: a review. Crit. Rev. Food Sci. Nutr. 48: 877-87. 
Ali A, Yusra M. Al-Kindi and Al-Said F 2009. Chemical composition and glycemic index of three varieties of Omani dates. Int. J. Food Sci Nutri. 60: 51-62.

Altschul SF, Gish W, Miller W, Myers EW and Lipman DJ 1990. Basic local alignment search tool. J. Mol. Biol. 215: 403-410.

Bauer AW, Kirby WM, Sherris JC and Turck M 1966. Antibiotic susceptibility testing by a standardized single disk method. Am. J. Clin. Pathol. 45: 493-496

Berger CN, Sodha SV, Shaw RK, Griffin PM, Pink D, Hand P and Frankel G 2010. Fresh fruit and vegetables as vehicles for the transmission of human pathogens. Environ. Microbiol.12:2385-2397

Beuchat LR 2002. Ecological factors influencing survival and growth of human pathogens on raw fruits and vegetables. Microbes Infect. 4: 413-423.20.

Brooks GF, Caroll KC, Butel JS and Morse SA 2007. Jawetz, Melnick and Adelberg's Medical Microbiology. 24th ed, The McGraw-Hill Co. New York, pp. 224-230.

Cappuccino JG and Sherman N 1996. Microbiology: A Laboratory Manual, 4th ed. The Benjamin Cummings Publishing Co. California. pp. 13-182

CLSI 2006. Performance standards for antimicrobial disk susceptibility tests: approved standard 9th ed. Clinical and Laboratory Standards Institute, document M2-A9, 26:1-37.

Dayani O, Khezri A, Moradi AG 2012. Determination of nutritive value of date palm by-products using in vitro and in situ measurements. Small Rum. Res. 105: 122-125.

Entani E, Asai M, Tsujihata S, Tsukamoto Y and Ohta M 1998. Antibacterial action of vinegar against foodborne pathogenic bacteria including Escherichia coli O157: H7. J. Food Protection. 61(8): 953-959.

Falkiner FR 1998. The consequence of antibiotics used in horticulture. J. Antimicrob. Chemother.41: 429-431

Hasnaoui A, Elhoumaizi MA, Asehraou A and Hakkou A 2010. Chemical composition and microbial quality of main varieties of dates grown in Figuig oasis of Morocco. International J Agri Biol. 12: 311-314.

Holt JG., Krieg NR, Sneath PHA, Staley JT and Williams ST 1994. Bergey's manual of determinative bacteriology Baltimore, Maryland: Williams \& Wilkins

Islam A, Mazumdar RM, Fakruddin M, Islam S, Nipa M N, Iqbal A and Bhuiyan H R 2010. Multiple antibiotic resistant bacteria on fruits from different markets of Chittagong city in Bangladesh. Bangladesh J. Res. Pub. 4(4): 332-40.

Kabir MS and Tasmim T 2019. Isolation of pectinase producing bacteria from the rhizosphere of Andrographis paniculata Nees and 16S rRNA gene sequence comparison of some potential strains. Advan. Microbiol. 9: 1-13.

Kumar S, Stecher G and Tamura K 2016. MEGA7: Molecular evolutionary genetics analysis version 7.0 for bigger datasets. Molecular Biol. Evol. 33: 1870-1874.

Maffei DF, Batalha EY, Landgraf M, Schaffner DW, Franco BD 2016. Microbiology of organic and conventionally grown fresh produce. Braz. J Microbiol. 47 (Suppl 1): 99-105.

Sarker MAR, Haque MM, Rifa RA, Ema FA, Islam MA and Khatun MM 2018. Isolation and identification of bacteria from fresh guava (Psidium guajava) sold at local markets in Mymensingh and their antibiogram profile. Veterinary World 11(8): 1145-1149.

SASO (Saudi Arabia Standards Organization). 1998. Microbial limits for food stuffs, Part 1. p. 26.

Saleh FA and Otaibi MM 2013. Antibacterial activity of date palm (Phoenix dectylifera L.) fruit at different ripening stages. J. Food Process Technol. 4(12): 1-6.

Shah MM, Odoyo E, Larson P S, Apondi E, Kathiiko C, Miringu G and Ichinose Y 2015. First report of a foodborne Providencia alcalifaciens outbreak in Kenya. Am. J. Trop. Med. Hyg. 93(3): 497-500.

Shomer I, Borochov-Neori H, Luzki B and Merin U 1998. Morphological, structural and membrane changes in frozen tissues of Madjhoul date (Phoenix dactylifera L.) fruits. Postharvest Biol. Technol. 14: 207-215.

Tamura K and Nei M 1993. Estimation of the number of nucleotide substitutions in the control region of mitochondrial DNA in humans and chimpanzees. Molecular Biol. Evol. 10: 512-526. 
Thabet I, Francis F, de Paw E, Besbes S, Attia H, Devanne C, Blecker C 2010.Charcterisation of proteins from date palm sap (Phoenix dactylifera L.) by a protein approach. Food Chem. 123: 765-770.

Thompson JD, Higgins DG and Gibson TJ 1994. CLUSTAL W: Improving the sensitivity of progressive multiple sequence alignment through sequence weighting, position-specific gap penalties and weight matrix choice. Nucleic Acids Res. 22: 4673-4680.

Wie S 2015. Clinical significance of Providencia bacteremia or bacteriuria. Korean J. Intern. Med. 30(2): 167-169.

Woo PCY, Lau SKP, Teng JLL, Tse H and Yuen KY 2008. Then and now: use of 16S rDNA gene sequencing for bacterial identification and discovery of novel bacteria in clinical microbiology laboratories. Clin. Microbiol. Infect. 14: 908-934.

Yoh M, Matsuyama J, Ohnishi M, Takagi K, Miyagi H, Mori K, Park K-S, Ono T, Honda T 2005. Importance of Providencia species as a major cause of travellers' diarrhoea. J. Med. Microbiol. 54: 1077-1082.

Yuan C, Wei Y, Zhang S, Cheng J, Cheng X, Qian C, Wang Y, Zhang Y, Yin Z and Chen H 2020. Comparative genomic analysis reveals genetic mechanisms of the variety of pathogenicity, antibiotic resistance, and environmental adaptation of Providencia genus. Front. Microbiol. 11: 572642.

Zamir R, Islam ABM, Rahman A, Ahmed S and Faruque MO 2018. Microbiological quality assessment of popular fresh date samples available in local outlets of Dhaka city, Bangladesh. Int. J. Food Sci. 2018: $1-4$. 